\title{
Protecting biocultural diversity at Kazdaği National Park, Balikesir, Turkey: the role of Sacred Natural Sites
}

\author{
Yilmaz Ari* \\ Bandirma Onyedi Eylül University, Turkey
}

Official nature conservation efforts have lasted a little more than a century in the world. However, the history of protection of Sacred Natural Sites (SNSs) by local cultural groups goes back thousands of years because these places have sacred value and meaning for them. This article documents, categorises, and maps the SNSs in Kazdağı National Park (KDNP), one of the most significant national parks in terms of biocultural diversity. Official nature conservation practices in the area focus on preserving biological resources but neglect cultural, sacred, and spiritual resources and practices inside the park. 24 SNSs have been identified in and around the KDNP, and have been categorised and mapped based on their characteristics. The study identifies how SNSs are protected by traditional ecological knowledge (TEK) and discusses how they can be integrated into modern nature protection programs. SNSs can provide an opportunity for park managers to include more spiritual and sacred dimension to their work, yet they might cause overcrowding of protected areas because of excessive tourist flows. Therefore, careful planning balancing the biological and cultural approaches, and being both locally inclusive and participatory, is necessary. Recognising and including SNSs in protected area management practice will both protect the rights of local communities and ensure the sustainable use of natural resources.

Key Words: sacred natural sites, nature conservation, biocultural diversity, Kazdaği National Park, Turkey.

Article Info: Received: May 29, 2020; Revised: September 18, 2020; Accepted: September 30, 2020; Online: November, 30, 2020.

\section{${ }^{*}$ Correspondence address}

Address: Bandirma Onyedi Eylül University, Faculty of Human and Social Sciences, Department of Geography, Bandirma, Balıkesir, Turkey

Phone: +902667170117 | Email: yari@bandirma.edu.tr

(C)2020 Human Geographies; The authors 


\section{Introduction}

People's attachment to nature for cultural and spiritual reasons has helped us understand the sustainable nature of the human-environment relationship. Considering some natural places as sacred is one of the oldest traditions of human communities and perhaps the oldest form of nature protection (Berkes \& Folke, 1998; Dudley et al., 2009). Fear of nature, whether in traditional or modern societies, has led to respect and worship in places known as Sacred Natural Sites (SNSs). SNSs can be any landscape features, including lagoons, springs, lakes, ponds, rivers, creeks, waterfalls, hilltops, mountains, and geomorphologic features such as rocks, cliffs, or caves, forests, groves, or trees. Some of these places have human-made structures, such as tombs, mosques, shrines, churches, or other worshipping places. Some of these may be linked to historical events, legends, or stories. All these places are called SNSs because of the significance of natural attributes they possess. The human-made structures attached to them are also considered as part of SNSs (Berkes, 2012; Verschuuren et al., 2010). SNSs attract visitors to a large extent. These visitors can be locals for spiritual, religious, or cultural reasons (Uzun \& Yıldız, 2020), popular or traditional tourists (Arı, 2008), and adventurers.

Yet, the spiritual relationship to nature has been lost in many parts of the world, especially in modern societies, due to several factors. It is argued that developed countries' materialist culture sees nature and culture as separate entities as subject and object, religious and secular, mind and body (Thorley \& Gunn, 2008). Some scholars argued that this is because nowadays, people have a lesser degree of experience with nature, and pay less attention to their spiritual, sacred, and cultural ties with nature than in the past. For this reason, whether the spiritual values or the economic and ecological values of the SNS should be prioritised has emerged as a vital dispute (Rutte, 2011). As a result, the physical environment goes through a process called "de-sacralisation" through the loss of traditional worldviews (Nasr, 1996). One of the reasons de-sacralisation takes place is because some arrangements such as nature conservation efforts can put a barrier between local and traditional societies and the environments. The Kazdağ National Park (KDNP), in northwest Turkey, is one of these areas.

Located in a transition zone, Kazdağları (Mount Ida in mythology) has been a source of life for centuries for local communities. There have been two dimensions of the relationship between the mountain environment and local communities. The first is the dependency of local communities on the park's resources for their livelihood. The second is the use of SNSs by local people for religious and spiritual reasons. Numerous areas, some of which belonged to the pre-Islamic period and were attributed to sanctity, are either within the boundaries of the national park or neighbouring it (Hurley \& Ar1, 2011; 2018). Park administrators have prevented access to the resources traditionally used by local people, but have opened them to the non-locals, and mass tourism has been adopted in the area (Ar1 \& Soykan, 2006a; 2006b). This created tension between the park's 
administrators and the local people. The desire of local groups to use SNSs was one of the main causes of tension between the two parties.

Since its declaration as a national park in 1993, many studies have been done about the protection of the species and other conservation issues in the area. However, these studies focused mostly on the conservation of biological resources and neglected the cultural values and SNSs. Unfortunately, not much progress has been made as to how SNSs and traditional ecological knowledge (TEK) should be integrated into official nature protection programs. Therefore, this study aims to identify, document, categorise, and map the SNSs in and around the KDNP and suggest ways in which the SNSs can be used for sustainable management of the park's resources. Considering the SNSs in the management practice of the protected area will secure the rights of the local communities as well as guarantee the sustainable use of natural and cultural resources of the national park in a more holistic manner.

\section{Towards integrating SNSs in nature protection}

SNSs were defined by Dudley et al. (2005) as: "areas of land or water having special spiritual significance to peoples and communities" (Wild \& McLeod, 2008:1). SNSs are parts of different landscapes. They might be a part of wooden areas such as a single tree, groves or entire forests; part of a morphological unit such as peaks, caves, rocks, cliffs or an entire mountain; part of a water body such as a river, lake, pond, spring or waterfall. In addition, they might include landscapes that might harbour human-made structures such as temples, churches, mosques, shrines, tombs or other burial places (Dudley et al., 2009). Local communities and indigenous people use SNSs for mainly spiritual purposes. The SNSs provide them with the opportunity to practice their unique culture, and this helps maintain cultural diversity and it, in turn, helps maintain the resilience of cultural systems (Pretty et al., 2009). Researchers determined that while maintaining cultural diversity, the SNSs, are affluent biodiversity areas. Yet, compared to non-sacred areas, they are used more often; therefore, they are considerably more threatened.

Until recently, nature conservation studies targeted biodiversity, and previous studies mostly focused on increasing and maintaining wild plant and animal species. However, some recent studies show that the world's biodiversity areas and cultural diversity areas intersect broadly (Harmon, 2007; Stepp et al., 2004). Thus, biodiversity which is measured by birds, mammals, and plant diversity, and cultural diversity which is measured by the number of languages, ethnic groups, and religious diversity are mostly concentrated in the same areas. Therefore, it is stated that nature conservation can only be achieved through a new term that includes both types of diversity, and is called bio-cultural diversity. The concept of bio-cultural diversity aims to protect cultural diversity with its different elements and natural life in all aspects. It can be defined as: "Biocultural diversity comprises the diversity of life in all of its manifestations-biological, cultural, and 
linguistic-which are interrelated...within a complex socio-ecological adaptive system" (Maffi, 2012:5). SNSs are essential elements of biocultural diversity as they are an integral part of the culture of traditional societies.

Although the relations of local communities with SNSs are very old in all parts of the world, they came to the agenda of researchers only after the 1990s (Berkes, 2008; Posey, 1999; Verschuuren et al., 2012). The tradition of attributing holiness to nature is widespread, and there are probably millions of SNSs on a global scale. Moreover, when people migrate, they tend to create new SNSs. Thus, the SNSs that declined by secularisation are balanced by those created by people migrating and settling in other parts of the world. The reason for sacredness in these areas can come from multiple events and sources. These areas can be the site of a significant historical event; a burial site, a place of God, a holy person, or a place associated with legends (Jackson \& Ormsby, 2017).

Although the number of SNSs is high, and some of them are located in protected areas, their significance for nature protection is not fully appreciated (Dudley et al., 2003). This is because the critical role SNSs can play in nature protection is not understood by officers in the field. However, there have been significant developments in the last 15-20 years in terms of stressing the value of SNSs. The local communities' use of areas containing SNSs and their religious and sacred and spiritual uses are started to be especially recognised. The United Nations Declaration on the Rights of Indigenous Peoples (UNDRIP, 2007) is considered a key document in this regard, and it noted that local communities have the right to hold, develop, and teach their sacred and religious ceremonies and practices, as well as the right to freely access and protect the places where these practices are carried out.

Both the SNSs in and outside of the protected areas face threats from modern society's lifestyle. These may be due to excessive population growth, change in land cover and land-use practices, mining, urbanisation, agriculture, forestry, excessive tourism, or neglect (Wild \& McLeod, 2008). Because of all these threats, SNSs is considered one of the keys to protecting cultural diversity.

Although the SNSs have played an essential role in human-environment relationships throughout history, SNSs have not been a priori research subject in conservation literature until recently (Pungetti et al., 2012). The SNSs came to the agenda of researchers as a global issue only in the last two decades (Berkes, 1999). Thanks to the efforts of the International Union for the Conservation of Nature (IUCN), United Nations Educational, Scientific and Cultural Organization (UNESCO) and the Convention for Biological Diversity, more research has been conducted on SNSs since the beginning of the 2000s (Adams, 2003; Oviedo et al., 2005; Schaaf \& Lee, 2006). Some NGOs started to prepare reports on the significance and management of SNSs and the critical role they can play in conserving nature. These reports documented sacred sites in several countries and investigated the reasons for visiting and using these sites by local and indigenous groups. They also developed the principles for protected area managers and suggested ways of protecting and using the SNSs for nature conservation (Anderson et al., 2005; Mallarach \& Papayannis, 2007; Verschuuren 
et al., 2007). The IUCN prepared a guideline for protected area managers, describing practical ways for recognising and integrating SNSs, promoting collaboration with stakeholders, understanding and improving the knowledge of SNSs, protecting SNSs while allowing local usage, and respecting the rights of SNS custodians (Wild \& McLeod, 2008). Although these principles provide significant protection for SNSs worldwide, they are still general in nature. They need to be adapted to local conditions for the management of many different SNSs (Mallarach, 2010). These reports also documented the factors and global changes affecting the SNSs and suggested ways to acknowledge the traditional uses and how these uses can be integrated into current conservation initiatives. Many case studies around the world demonstrated the local people's relationship to SNSs and documented the indigenous ways of managing these sites (Campbell, 2005; Frascaroli et al., 2014; Metcalfe et al., 2009; Samakov \& Berkes, 2017; Tengö \& von Heland, 2011).

Although SNSs are primarily areas used by local communities for spiritual reasons, they also serve the socio-cultural, economic, political, and psychological purposes of societies. For example, it is known that sacred forests and groves in India have psychological, health, economic and social purposes. In this context, festivals and social gatherings are organised, and wedding ceremonies are held in sacred areas. The SNSs also support the development of group identity and morale, increase fertility, and help solve other health problems (Malhotra et al., 2001). Sacred forests are the main protected areas of plants used in the pharmaceutical industry in Sierra Leona (Lebbie \& Guries, 1995). Almost onethird of the sacred sites provide protection to plants in IUCN's list of threatened species (Colding \& Folke, 1997). Tibetan sanctuaries also overlap with biodiversity sites and are mostly protected by monasteries (Shen et al., 2012).

It is widely accepted that Western societies are less connected with nature. However, there is a renewed interest in sacred areas in Western societies, and the main reason for this interest is environmental disasters and economic collapse. In order to protect themselves, Western societies look at their historical origins and protect their cultural heritage. Sacred sites are among the most important of these cultural heritage sites. For example, Stonehenge in the UK and Newgrange in Ireland are examples of such places. Interest in these places is increasing for tourism, entertainment, education or business purposes (Thorley \& Gunn, 2008). Tourism seems to be one significant type of use for SNSs, but it has certain effects on these sites. For example, Arı (2008) documented the negative impacts of tourism on SNSs at KDNP in Turkey, and Frascaroli (2013) reported that tourism, weather religious or secular, has negatively affected the sacred areas in central Italy.

There are perhaps thousands of SNSs throughout Turkey as well. The Anatolian peninsula has a long history of people of different origins. Valuing and attributing sacredness to nature has been an essential practice among these various communities (Tatar, 2017). Although there has been extended literature on sacred sites in Anatolia, they have not been evaluated with the perspective of nature conservation. SNSs have been the subject to several studies at Kazdağları. 
Duymaz (2001) reported that the sacredness attached to Kazdağı is mostly because of the Sarıkı Legend and tomb of Sarıkız at one of the summits. Duymaz \& Sahin (2008) also documented the sacredness attributed to the mountain, trees, and quarries used during the rituals to bless Sark 1 and his father at KDNP. However, these studies made no connection between sacred sites and nature conservation. Only a few studies linked sacred sites and nature conservation at KDNP and investigated the impact of traditional and spiritual rituals inside KDNP to SNSs (Arı, 2004; Arı \& Soykan 2006a; 2006b; Arı \& Köse 2009). These studies suggested ways to protect the biocultural resources of the KDNP by changing the management approach to include more cultural elements and social science. Studies also documented the role of beliefs and traditions in other parts of Anatolia and showed how the sacredness attached to some places can protect the wildlife in these areas (Bulut 2011; Çetin et al., 2017 Öner et al., 2010; Uzun \& Yıldız, 2020; Yürüdür \& Toksoy, 2017).

\section{Study area}

As one of the most well-known national parks in Turkey, the KDNP is situated in NW Turkey, inside Balikesir province, bordering Çanakkale to the north of the Bay of Edremit just across from the Greek Island of Mytillene (Figure 1).

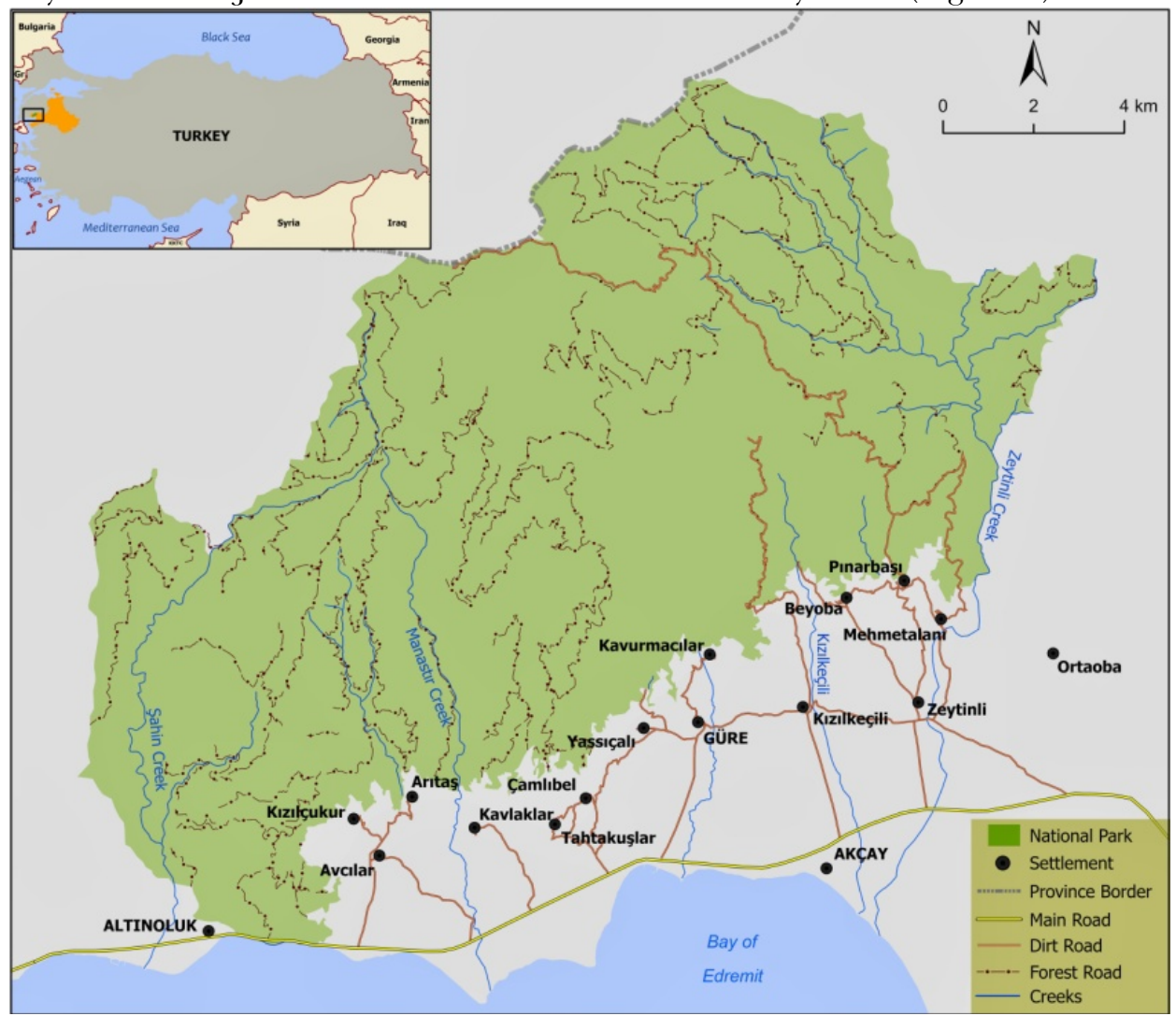

Figure 1. The location map of KDNP 
The primary motivation for the establishment of the park was to protect the rich plant diversity of the area, including 800 taxa of plants of which 32 are endemic. The area also has unique geomorphologic units such as cliffs and canyons, and wild animal species such as wild pig and bear, among others (Satıl, 2009; Uysal, 2010). There are many beautiful types of scenery, with tourists coming here to see these places and also the Edremit Bay, Troy and the Aegean Islands, especially the island of Mytillene. The Kazdağı region is known for its beautiful and refreshing air, which is thought to affect some diseases, such as asthma positively. The shores of Edremit Bay, just to the south of the mountain have been flooded by amenity migrants in the last 20-30 years since it has many positive features such as scenery, clean air and abundant and beautiful water resources. As a result, this area, where only secondary houses were built before, has been occupied by the new settlers and the land commodification has emerged as an essential feature of the area (Hurley \& Arı, 2018). This area is known in mythology as the mountain with a thousand springs and is supporting of all this population through its water resources. The Bay of Edremit is now a popular tourist destination in the summer, attracting almost two million people annually in addition to the amenity migrants who settled in the area (Özkan \& Uzun, 2019; Uzun \& Özkan 2019). In 2019, for example, 1,984,748 tourists visited the Bay area, and 113,625 of them entered the national park for mostly visiting the SNSs (South Marmara Development Agency, 2020; Bureau of the Balıkesir National Parks, 2020). Kazdağı also attracted the attention of international mining companies due to its significant gold deposits, and this caused severe conflicts between local people, environmental organisations and mining companies (Avcl et al., 2010; Avc1, 2017).

\section{Methodolgy}

The primary data used in this study were collected by the author through fieldwork in and around KDNP. The author conducted numerous studies in the research area in the last 15 years. These included studies identifying the impacts of cultural and spiritual uses of the park on natural resources (Arı, 2004); documenting the economic and social impact of the KDNP on local communities (Arı \& Soykan 2006a; 2006b); tourist's motivation at KDNP (Arı, 2008); ethnobotanical uses of KDNP's resources by local people (Satıl et al., 2006); carrying capacity of the KDNP (Dereli \& Arı, 2012); attitudes towards gold mining (Hurley \& Arı, 2011) and land commodification on the southern slopes of KDNP (Hurley \& Arı, 2018). All this work required extended fieldwork at the site. During these fieldwork sessions, which continued for many years, the items observed included how local people used mountain resources and especially the SNSs in ceremonies, celebrations, sacrifices and dedications. In August, when the rituals were intense, the use of SNSs was determined on-site and recorded employing observation, sometimes supplemented by overnight stays. The specific data on SNSs were collected and re-checked through extended fieldwork in the 
summer months of 2018 and 2019, when three fieldwork sessions were conducted, each lasting seven days.

When this study started, there were no inventory lists of sacred places in KDNP. In order to make this inventory, all village headmen (mukhtars) at the borders of the KDNP were interviewed separately. The areas that the people in these villages regarded as sacred and the reasons for their perception were determined. Later, this information was confirmed by more than five people randomly selected from the closest village, and the few faulty ones were corrected and recorded. Then, participant observation was done at each of the sites to determine the usage of the sites. Traditional rituals in the area were observed, recorded, and photographed during the fieldwork sessions. Then, the opinions of the national park officials about these places were taken. However, since park managers focused on biological resources, they only learned the existence of some of the sacred places during the study. After determining the reasons for sacredness for all these areas, the SNSs were categorised and mapped by using ArcGIS Pro, 2.5 Software.

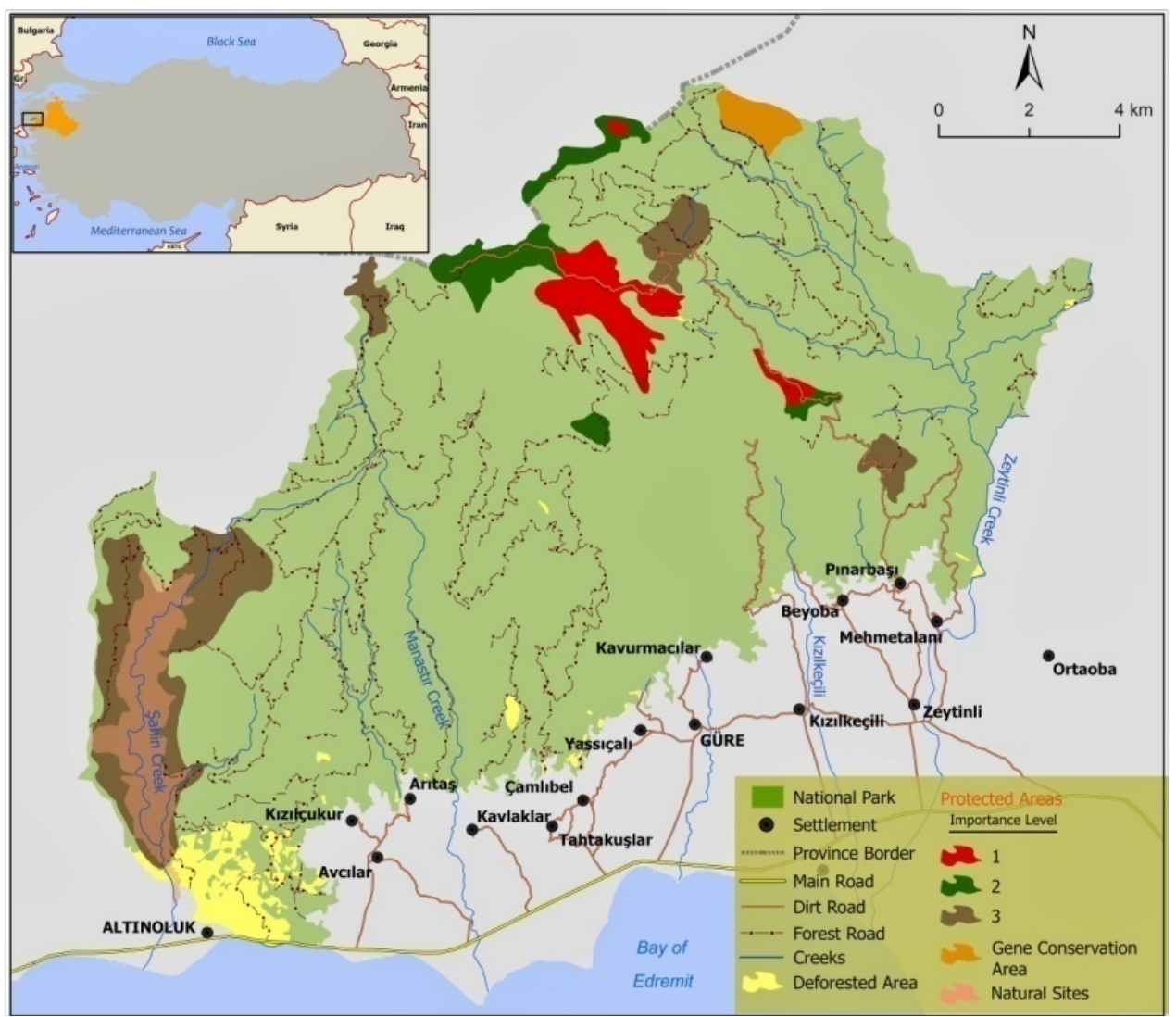

Figure 2. Important plant areas at KDNP

Then these sites were evaluated based on their properties in terms of importance for endemic and rare plant species. A previous study (Satıl et al., 2006) documented and mapped (Figure 2) the important plant areas and categorised 
these areas into three groups according to their status depending on the categories determined by the IUCN. This map was overlaid with the map of sacred sites at KDNP to see the relationship between SNSs and biological diversity.

\section{Sacred natural sites at Kazdagi National Park}

In traditional pre-Islamic Turkish belief, the mountains were perceived to be sacred because of their proximity to the Sky God and because it was believed that God lived in the mountains. In addition, the mountains were perceived to be the protectors of the people living around them. Many of the rituals associated with God were held at the top of the mountains. The Turks gave the names they used in Central Asia to places in Anatolia and formed a cult in these places. Many tombs were placed on hills and peaks, and famous persons were buried in these places. The landscape of Kazdağı is also dotted with these sacred hills harbouring the tombs of holy persons. These places have become the natural temples that allowed local communities to sacrifice animals, pray, and contact the sacred. It is possible to say that the Turks revived their thoughts about the holy mountains in Anatolia and made them liveable. One of these places is Kazdağı (Duymaz \& S,ahin, 2008).

Kazdağ 1 is perceived to be a sacred landscape as a whole because of legends told among local populations. The legends date back thousands of years, and some of them were told in the pre-Islamic period and somehow continued among local communities in the Islamic period, and new ones were added. Today, the Tahtacı Turkomen and Yörüks, the two distinct cultural groups living in the immediate area of the park, inherited some of these earlier views in addition to their beliefs brought from Middle Asia. The name, Kaz (meaning goose) was given the mountain because the goose is believed to fly in the highest attitude; therefore, it is closest to God. This way, a connection is made to God through the mountain.

Today the sacredness of the mountain is mostly associated with the Sarıkız Legend and rituals related to that legend (Duymaz \& S,ahin, 2008). According to the legend, a blond-haired girl living in the village of Kavurmacilar was taken to Kazdağı by her father for her unacceptable social behaviour and left there as prey for wild animals. However, her father found out that his daughter had been slandered and that she was an Awliya (a person who has extraordinary, holy power and abilities). He then decided to live with her until the end of his life. The symbolic tomb of the girl is now on one of the hills; with her father supposedly dying on another hill being buried there. Both hills are now considered sacred. Today, the most visited point of the park is the hill where the Sarkiz tomb is located (Figure 3, Photos 5-7). Locals come here for 7-10 days at the end of August every year, and they hold religious ceremonies, sacrifice animals, and pray. Help is also requested from Sarkkı, who is believed to be a holy woman. During these activities, Alawi peasants stay at Kartal Çimen and the Yörükler at the location called Güllüce (Photos 1-4). 

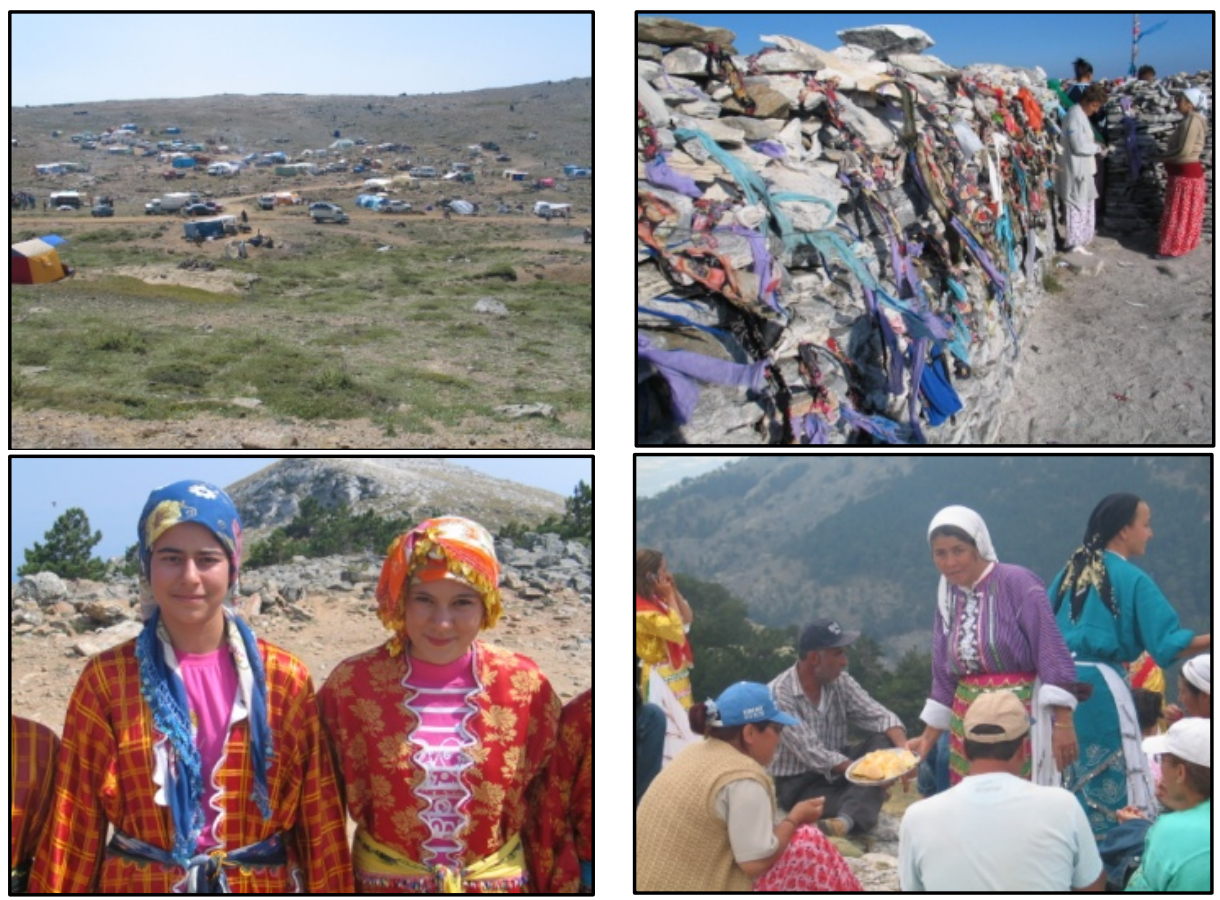

Photos 1-4. The Kartal Çimen where the Sarıkız rituals take place at the top of Kazdağı. Kartal Çimen, Sarıkız Tomb, and Turkomen women in traditional dresses are offering food to fellow villagers

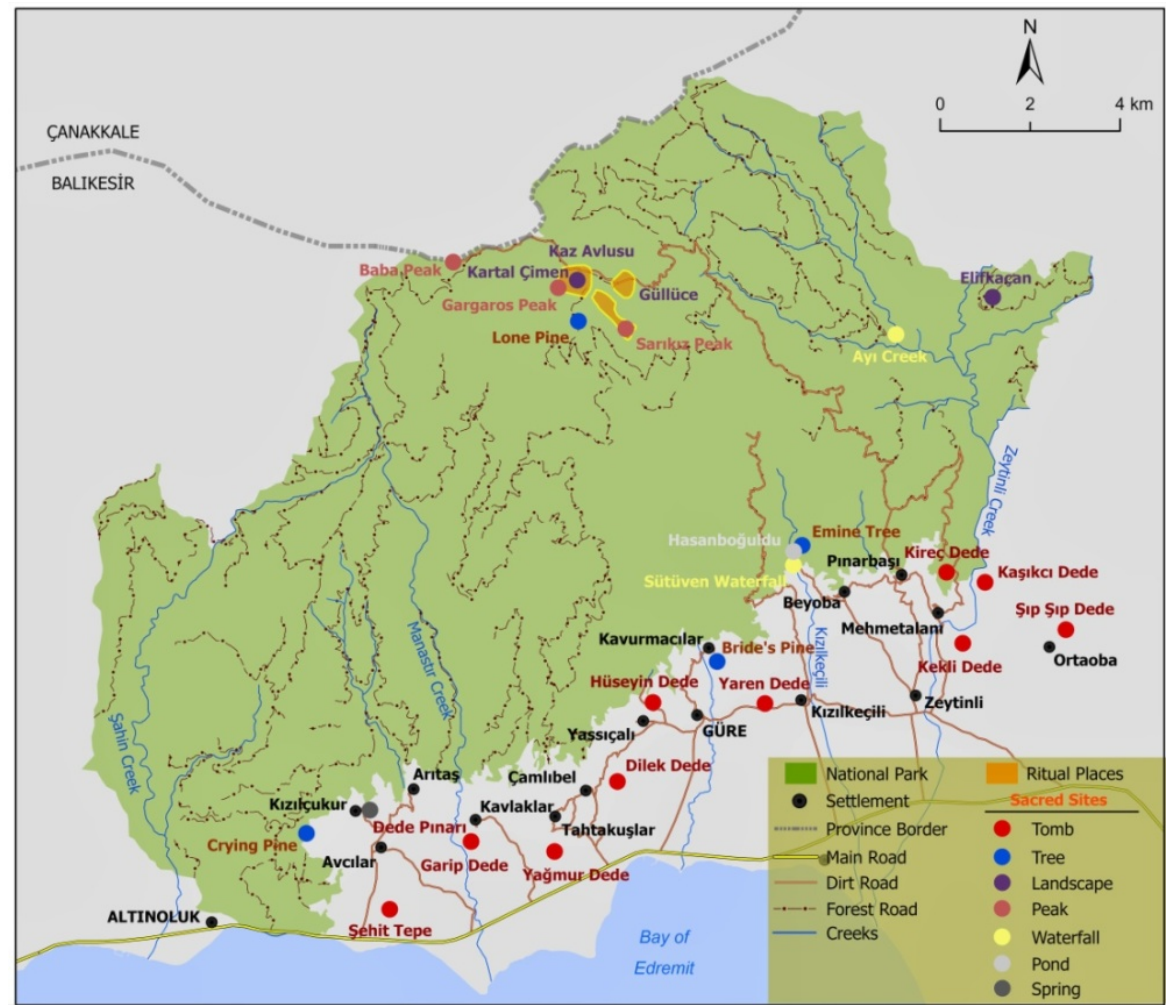

Figure 3. Map of sacred sites in and around KDNP 
The Hasan Boğuldu legend holds that Hasan, a rich and urban person, falls in love with Emine, a poor peasant daughter from one of the villages at the foot of Kazdağı. Traditionally, such a marriage is not allowed because it was believed that urbanites were not strong and durable enough. In order for Hasan to unite with Emine, he must carry a sack of salt from the sea coast to the top of the mountain. However, Hasan climbed a rock on the mountain slope, and fell out into a pond and choked. Being very upset about this, Emine committed suicide by hanging herself from a plane tree which later called Emine Tree (Photos 8-11). The pond and the tree have also been one of the hotspots for tourists as the story is reproduced in literature and films and became known nationwide (Arı, 2004).

In addition to these well-known legends, there are legends only known to the locals, such as Elif Kaçan that features the love of a young man and woman from different cultural groups. The legend has it that when the youngsters decided to marry, the two communities opposed the decision, and the youngsters escaped to the mountain. Both sides went for a search, but suddenly, a dense fog came down as a miracle of a Dede, the Alawi religious leader, and covered the part of the mountain where they were hiding so that they could not be found. Overall there are many sacred places, consisting of hills, trees, water sources, and waterfalls (Table 1, Figure 4).

Table 1. Categorising SNSs in and around KDNP

\begin{tabular}{|c|c|c|c|}
\hline Category & Name of SNS & Sacred Site Description & Characteristics \\
\hline \multirow{4}{*}{ Peaks } & Sarıkız Tepe & Sarıkız's tomb & Natural+cultural \\
\hline & Gargaros Tepe & Zeus' place & Natural+cultural \\
\hline & Baba Tepe & Tomb of Sarıkız's father & Natural+cultural \\
\hline & Kaz avlusu & Sacred rocks surrounded Kartal Çimen & Natural+cultural \\
\hline \multirow[t]{4}{*}{ Landscape } & Kartal Çimen & Sacred alpine meadow & Natural+cultural \\
\hline & Elif Kaçan & Sacred because Elif disappeared here & Natural+cultural \\
\hline & Gelin Çamı & Believed in providing fertilisation & Natural+cultural \\
\hline & Ağlayan Çam & It feels the pain of humans & Natural+cultural \\
\hline \multirow[t]{7}{*}{ Trees } & Emine Çınarı & Emine hanged herself here & Natural+cultural \\
\hline & Yalnız Çam & Sacred as the place of a holly person & Natural+cultural \\
\hline & Dilek Dede & Place of a Dede & Cultural+natural \\
\hline & Kekli Dede & Place of a Dede & Cultural+natural \\
\hline & S,ıp S,ıp Dede & Place of a Dede & Cultural+natural \\
\hline & Kireç Dedesi & Place of a Dede & Cultural+natural \\
\hline & Kaşıkçı Dede & Place of a Dede & Cultural+natural \\
\hline \multirow{6}{*}{ Tombs } & Yaren Dede & Place of a Dede & Cultural+natural \\
\hline & Hüseyin Dede & Place of a Dede & Cultural+natural \\
\hline & Yağmur Dede & Place of a Dede & Cultural+natural \\
\hline & Garip Dede & Place of a Dede & Cultural+natural \\
\hline & Şehit Tepe & Place of Martyrs & Cultural+natural \\
\hline & Sütüven, & Earlier civilisations worshipped here & Natural+cultural \\
\hline Waterfalls & Ayı deresi & Sarıkız lived here & Natural+cultural \\
\hline Ponds & Hasanboğuldu & Hasan drawn here & Natural+cultural \\
\hline Springs & Dede Pınarı & Water brought out by a Dede & Natural+cultural \\
\hline
\end{tabular}




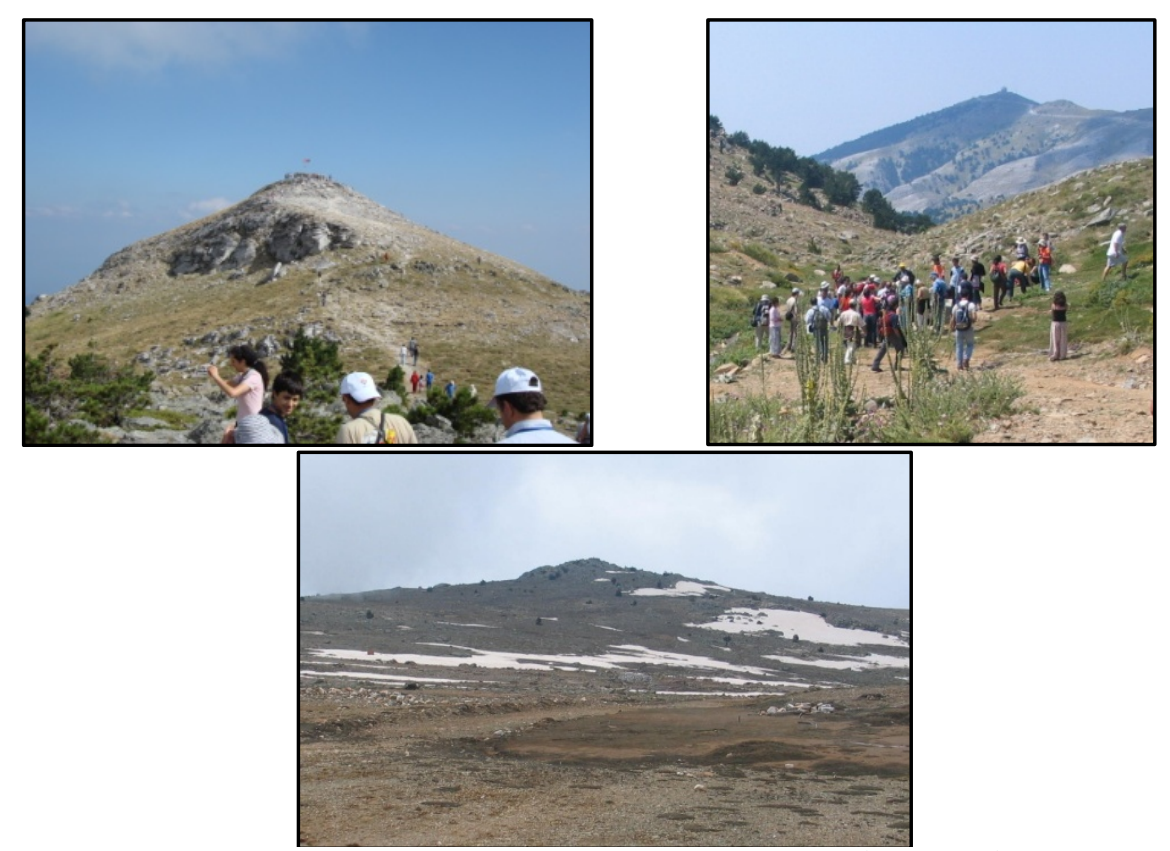

Photos 5-7. The sacred peaks of KDNP: Sarıkız peak, Karatepe (Gargaros) and Baba tepe

\section{Trees}

There are many sacred trees in the Kazdağı landscape. One of these trees, known as the bridal pine, stands alone as a majestic tree on a hill below Kavurmacilar Village (Berkes, 2012; Turner et al., 2009). It is believed that the newlyweds need to turn around this tree seven times just after the wedding so that they avoid infertility and have children as soon as possible. Nowadays, as shown in the Photos 8-11, thousands of locals and tourists gather under this tree during the Sarıkız charity held here at the end of August every year and afterwards go to Kazdağ for annual rituals devoted to Sarıkız. There is also a tree known as the weeping pine on the road from the Avcrlar village to the national park. It got this name because of its continually flowing resin. According to the story told among locals, this tree witnessed some event centuries ago and started to cry, and the tears never ceased. The Emine tree is the plane tree next to the Hasan Boğuldu pond, and, according to the legend, Emine, who could not unite with Hasan, hung herself here. This legend has been viral lately, as it has been reproduced in movies, books, and poems. There is another sacred isolated pine tree, the Yalnız Çam, next to the road to Sarıkız Tepe at the top of the mountain. The sacralisation process of this tree shows how new elements are added to sacred landscapes at Kazdağı. One woman who came to the region for Sarıkız rituals had a dream in August of 2003, and her dream showed that a holy person's grave was under this tree, and he asked her to remove the tents from his grave not to disturb him. With the author of this study's conscious encouragement, a few stones were placed around the tree at that time. After that year, the stones increased every year, and visitors started to tie pieces of cloth to the tree, which represent holly requests. Thus, a new sacred place started to appear in the Kazdağı landscape after 2003 
(Photos 8-11). This is a clear indication that while de-sacralisation is observed in some parts of the world, new sacred places are continuously created in some other areas.

\section{Tombs}

There are many tombs attributed to sacredness around Kazdağı (Photos 12-15). These tombs are often the graves of religious leaders who have lived in the area and believed to have miracles. These are usually found in hilly areas on the border of the park (Figure 4). They are simple structures symbolising the graves on the hills. The most distinctive feature of these hills is the protection of trees around them. In areas up to about $500 \mathrm{~m}$ above sea level, the natural vegetation was cleared, and olive trees were planted. However, the red pines that make up the natural vegetation in the region continue to live only in these hilly areas. The trees around these tombs are thought to have a bond with the person lying there and are protected by them. Thus, if it is damaged or cut down, it is believed that something terrible will happen to the person who does the act.

As sacred places, these areas are used extensively by both local people and tourists. Locals hold a celebration in one of the cemeteries from Tahtakuşlar village. During the Hidirellez holiday, which is on May $6^{\text {th }}$ every year, Alawi Turkmen living in the Kazdağı region go to the cemetery and have a picnic with the dead. That is why every family graveyard has a stovetop to prepare food.
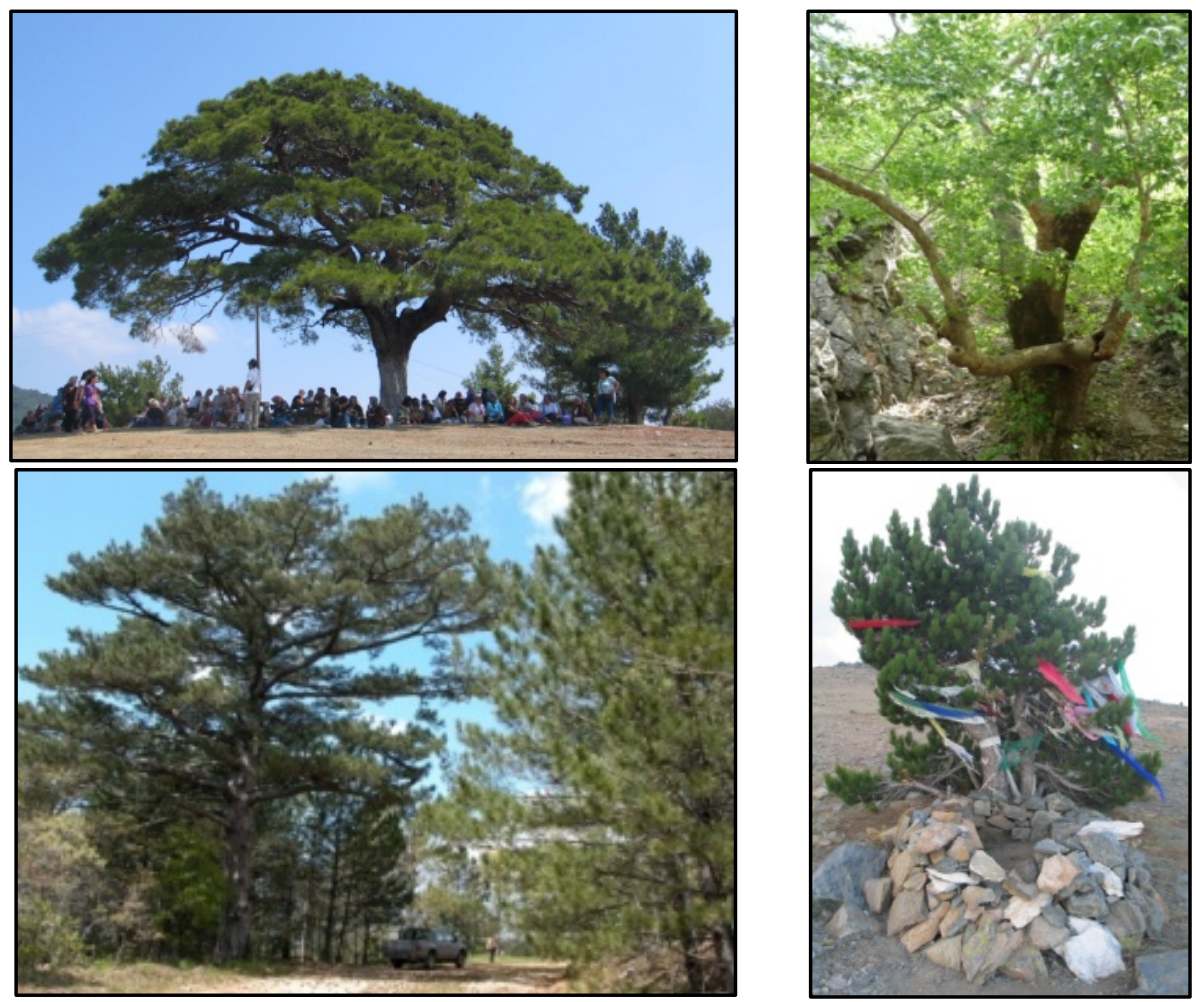

Photos 8-11. The sacred trees of KDNP: Gelin Çamı (Bride's pine), Emine Çınarı (Emine tree), Ağlayan Çam (Crying Pine) and Yalnız Çam (Lone pine) 

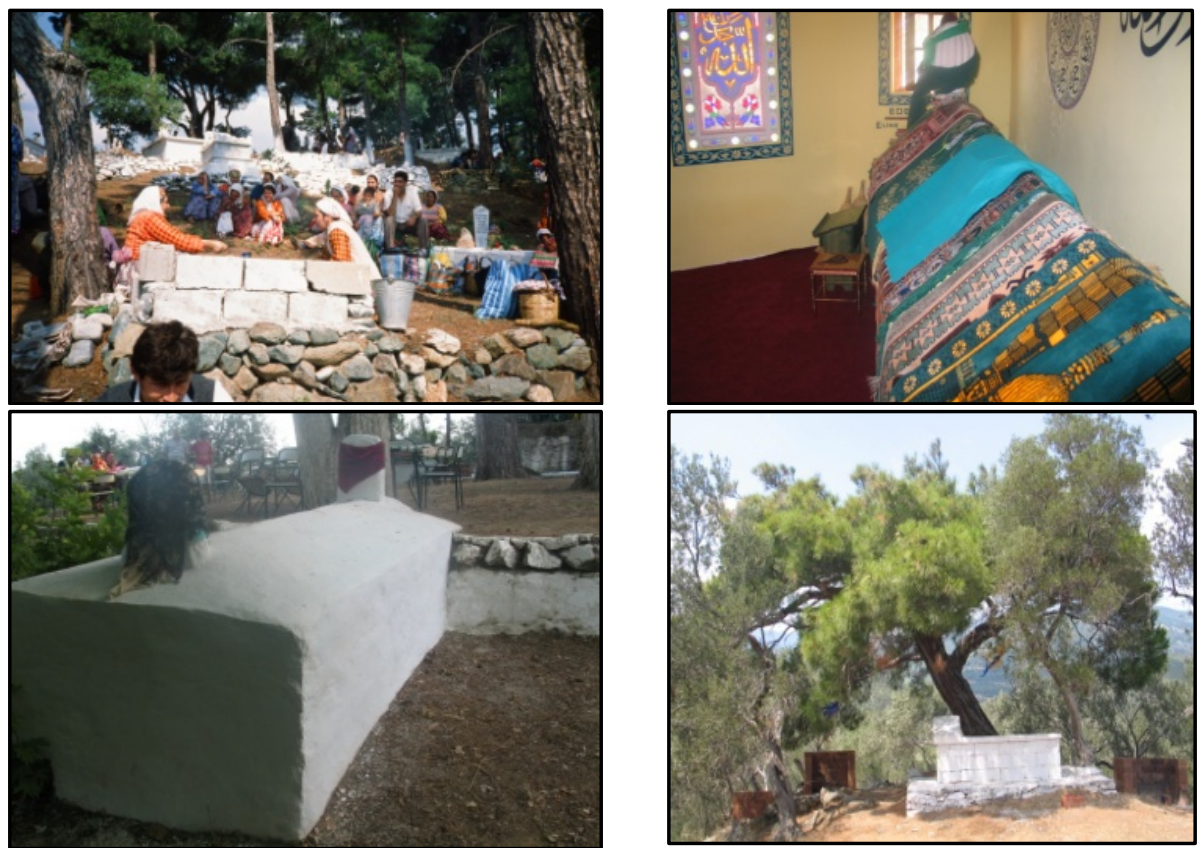

Photos 12-15. The sacred cemeteries and tombs at Kazdağı landscape. The Tahtakuşlar cemetery, the tomb of Şıp Şıp dede, and Kekli Dede at Mehmetalanı village

Meals are cooked and eaten here. Food and drinks are served to the dead as well because they believe that when people die, their life does not end but continues in another format. They only change their place and need food and drinks just like the living people. These drinks are usually alcoholic beverages. This is a contradiction, considering traditional Islam, but it shows the enduring influences of Shamanism on the Turkmen living in the region. This habit also manifests itself in the shoddy that is tied to the trees considered sacred in order to express the holly wishes of individuals. These places also attract the attention of tourists who have come to the region. It is impossible for someone interested in cultural tourism not to notice these sacred areas in the Kazdağı landscape.

\section{Waterfall and Ponds}

Kazdağları is known as "Ida Mountain with a thousand springs" in İlyada. The mountain gives life most significantly through its water resources. Some of these water resources have been attributed with holiness over time. One of them is the pond under a small waterfall where Hasan is believed to have drowned in the legend of Hasan Boğuldu (Photos 12-15). This pond is located within the national park's borders and is one of the park's most visited tourist areas. Tourists are taken here by guides, and they are told about the legend of Hasan Boğuldu. Emine Tree, right next to this pond, which is also perceived to be sacred. Also, the park's most known waterfall, the Sütüven Waterfall, is sacred. It is believed that its waters witnessed the entire history of the mountain and all the civilisations that lived here worshipped the spillage of the waterfall. 


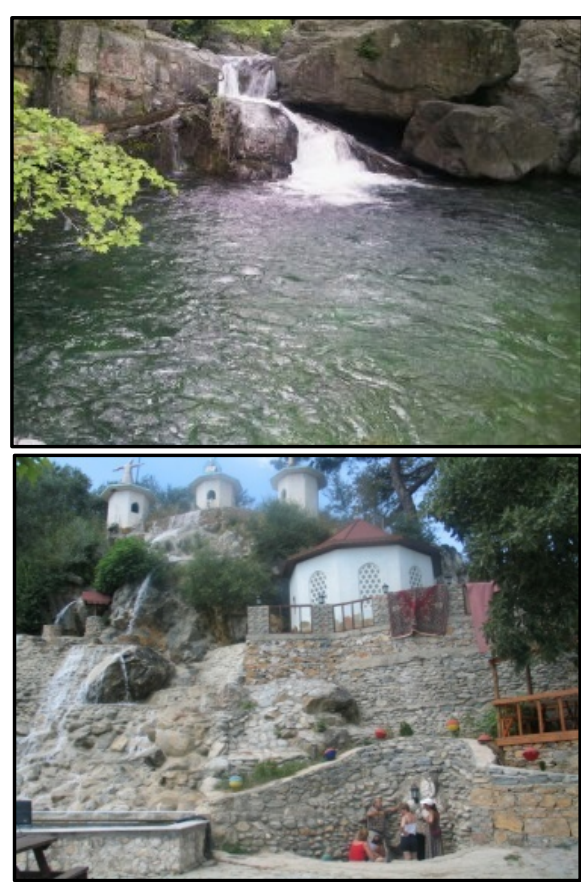

Photos 16-19. Sacred water bodies at KDNP

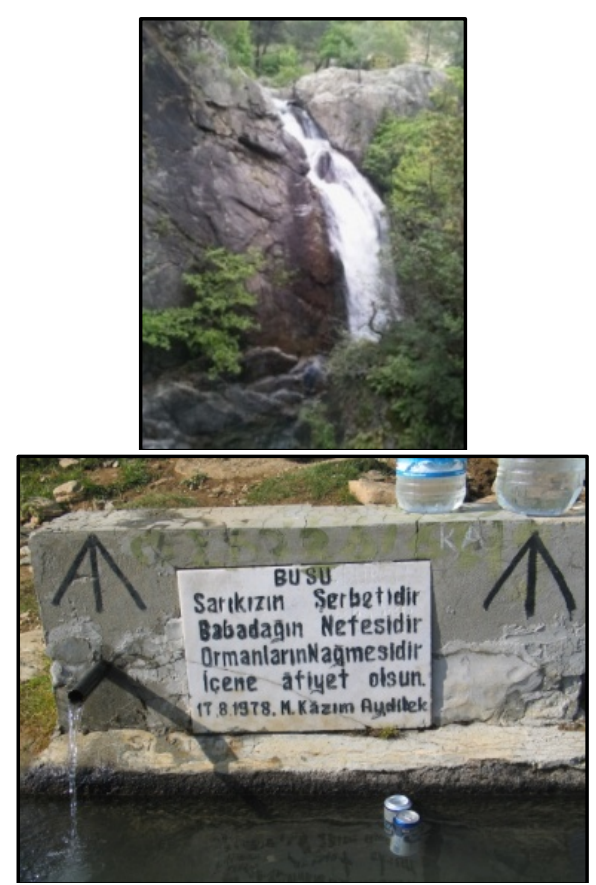

In the holy place called Sıp Șıp Dede where the tomb of a Dede is located, just to the west of the town of Edremit, it is believed that water determined the name of the Dede, the holly person. The inspiring sound of water dripping has given the name. This Dede is believed to have an extraordinary power to marry people and is called the "matchmaker Dede." The fountain at the end of the Kartal Cimen plain at the top of the mountain is also considered sacred because the water is believed to be the "sherbet of Sarıkı" and, it is written in its inscription that the drinkers of this water will find healing (Photos 16-19).

\section{Nature Conservation and SNSs at Kazdağı National Park}

Kazdağ 1 is in a transition area between the Black Sea and the Mediterranean climate, harbouring typical plants from both climate regions. The mountain also reaches $1774 \mathrm{~m}$ in a very short distance from the sea coast, making the area attractive in terms of geological and geomorphologic formations. The southern slopes of the mountain face the sun, while the northern slopes are more humid. All these features create a rich flora in the area. So far, 800 taxa plants have been identified, of which 32 are endemic. The Kazdağı area was declared a national park in 1993 in order to preserve this plant diversity. Its management system was established in 2000, and the use of the park's area by the local people was restricted. After this date, entries began to be made only in the company with local guides. The number of tourists coming here has increased significantly due to official policies that promote the area as a tourist destination. The local people's use of the area, especially during the Sarıkız rituals in August, coincides with the 
period of intense tourist flow and poses significant problems for visitor management in the park (Dereli \& Arı, 2012).

Like other protected areas throughout Turkey, the social dimension of nature protection seems to be missing at KDNP. Local people living around the Bay of Edremit have a close relationship with Kazdağları because the mountain has been a source of their livelihood, and they have been using the area for centuries for economic, religious, and spiritual purposes. With the declaration of the national park, relationship of local resource users with the mountain was significantly cut off. Sarıkız rituals, which used to be held for a month at the top of the mountain in August, were first banned but allowed to take place for shorter periods after a long struggle of the locals (Ar1, 2004). Likewise, collecting wood for fuel and construction, non-timber forest products, and grazing animals were banned, which significantly affected the economic situation of the local people who were dependent on mountain resources (Arı \& Soykan, 2006a; 2006b). After all these arrangements, the traditional relationship of the local people with the national park has been limited, and the park has been designed as an area for outside tourists. For this purpose, daily recreational areas have been made in certain parts of the park (Köse, 1997).

In the official website of the KDNP, the significant elements of the park are water resources, waterfalls, plant communities, endemic species, and wild animals. The concept used to express the national park is paradise of nature. This approach shows that the area is considered more as an essential tourist destination than as an important nature reserve. Thebe, Killa, Khrysa, Anderia, Antandros, Pedosos, and Astrya settlements were mentioned as cultural resources of the area in addition to three ancient cities located near the KDNP: Adramyttion, Antandros, and Assos ancient cities.

What is surprising is that the sacred sites documented in this study were never mentioned on the official website of the national park (KDMP, 2020). However, during the long-term fieldwork, it has been observed that planning local events, issuing permits to locals, arranging of visiting areas, and managing the visitors are the most critical issues among the daily works of national park administrators. In this sense, it is clear that there is an inconsistency between the theoretical planning of the park and daily practices. Nature conservation has been regarded as a science and tourism issue, but local practices prove that conservation is practically a social science, and park administrators have devoted most of their time to social issues and conflicts.

As shown in Figure 3, essential plant areas are the areas where the local population uses intensely. They have held their spiritual rituals and used these areas for different activities, including transhumance in the past. Biodiversity in these areas is expected to be less due to their excessive use under normal conditions. The question is how can there be such high plant diversity if local people have used these sacred sites for centuries. The answer can be found by searching for the TEK of local communities and their relations with nature (Berkes et al., 2000). In KDNP, TEK also helped protect important biodiversity areas as most of these areas overlap with SNSs. 


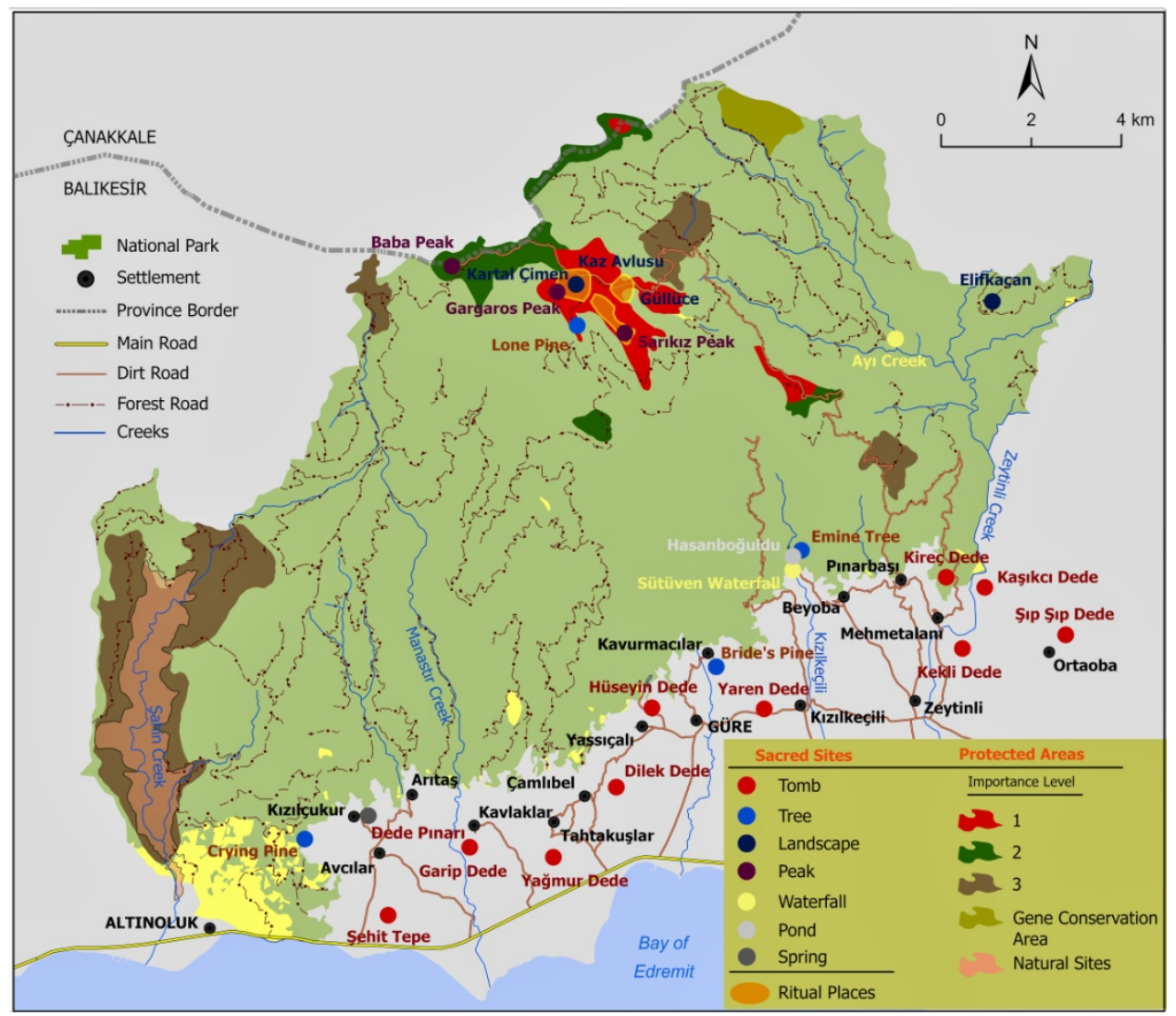

Figure 4. An overlaid map of SNSs and important plant areas at KDNP

The Alawi Turks who dominate the Kazdağı landscape today are originally Shaman people from Middle Asia and migrated to this region in the middle of the $15^{\text {th }}$ century. They still carry many elements from their original land, which has a more intense relationship with nature compared to other traditional Islamic communities. They use these sites intensely while creating new ones over time.

Local people are aware of the natural ecosystem and its elements, and they use forestry products from the mountain as a fuel source, food, or medicine. In this sense, the local people's ethnobotanical knowledge is extensive (Çelik et al., 2008; Satıl et al., 2006). In the process of declaring the KDNP in the early 1990s, a local person's response to the nature conservation officer who opened the idea of declaring the area as a national park is as follows: I cannot understand what will you protect that we have not protected so far, because we have been living here for centuries, and if you find resources to protect today, this is because of our respect for and protection of nature. What do you want to protect from whom I cannot fully understand this.

In fact, the locals are passionate about keeping the legends and beliefs about the mountain alive. Sarıkı rituals, which are held every year in August, beginning in the village of Kavurmacilar, located on the border of the National Park, where Sarıkız was believed to live (Figure 1). Here, traditional dishes cooked by the local municipality are served to thousands of people attending the ceremonies. These people sit in the shade of the sacred pine tree and eat their meals, accompanying 
the recitation of the Qur'an and prayers read for Sarıkız and other legends. After the ceremony is over, those who attend go to the top of Kazdağ 1 to stay at least one week and continue the ceremonies (Arı, 2004). Top activities are carried out precisely in areas with high biodiversity (Figure 4). Alawi Turks who used to live in western Anatolia used to go to Kazdağ during these ceremonies in pilgrimages. Nowadays, with the restrictions imposed by the national park administration, only those living in Edremit Bay participate, yet these religious and sacred ceremonies continue with the same excitement today.

Locals are meticulously protecting the areas where they perform ceremonies. In the local traditions, there are customs such as not cutting live trees from the forest and not collecting non-timber forest products that are not needed. Moreover, the areas of the mountain used for Sarıkız rituals are regularly looked after, and the necessary arrangements were made for the following year. In that sense, Sarıkız Tepe, Kartal Çimen, and Tozlu Yayla where celebrations and commemorations are held every year are regularly monitored by village headmen and activities that harm them are prevented. Fines have even been imposed by local village authorities on those who harm the resources in these areas (Ar1 \& Soykan, 2006b).

\section{Conclusions}

When it comes to SNSs, the KDNP is probably one of the unique parks worldwide. It has natural elements such as peaks, trees, water resources, landscapes, and cultural elements such as tombs, legends, and cemeteries. The site's current conservation practice does not take into consideration the SNSs, although the issues related to the SNSs occupy a vital place in park managers' agenda. The excessive use of these areas mostly by the tourists is a concern for both conservation officials and local communities. In Kazdağı, as well as in other parts of the world, SNSs coincides with places with high biodiversity areas. Since the park is advertised as a touristic area, the number of visitors has increased rapidly, and some of these tourists showed interest in SNSs as ego-tourists (Ar1, 2008). Therefore, SNSs are under threat along with other resources of the park. In fact, before being formally protected, local communities took full responsibility for conserving both biological resources and the SNSs. However, since the official protection was proclaimed, conflicts started to emerge between local communities and park administrators regarding both the use and protection of SNSs. The main reason is the restrictions put by the park's management on the use of SNSs by local communities while allowing mass tourism to develop inside the park through official policies.

The sense of local community has gradually begun to disappear due to new settlers arriving, and summer visitors and several groups have emerged claiming to represent the local community. This makes it difficult for the local community to show a unified reaction. Those who depend on park resources for their livelihood want these resources to be used in a particular order, while those who 
have migrated here for perceived positive resource values demand that these resources be preserved because otherwise, these perceived values will be lost. During the rituals, most of these groups present themselves as local people and want to participate in the events and act like local, creating a new type of behaviour that can be called as the de-secularisation of amenity migrants. In this new behaviour, these migrants want to attach sacredness to certain parts of the landscape of the mountain and practice local traditions and rituals at certain times. This poses a challenge for the management of SNSs.

The guideline of IUCN should be followed by managers of this protected area to overcome these and other challenges. In that respect, the sacred sites in the KDMP must be added to the park's list of resource values and should be included in official web sites and other material about the KDNP. After the importance of the sacred areas is recognised and appreciated, the manner in which these sites will be to manage for nature protection purposes should be planned. Here, a distinction must be made between the SNSs that are used by tourists and the SNSs used by locals. In this distinction, special plans should be made for places such as Sarkkız Tomb, Hasan Boğuldu and Kartal Çimen, which are well known at the national level. That way, the SNSs can provide an opportunity for park managers to include more spiritual and sacred dimension to nature conservation efforts. However, there is also the risk of attracting more visitors than necessary. Therefore, careful planning, balanced between biological and cultural approach, locally inclusive and participatory, is needed to ensure the sustainable use of the park's resources.

\section{Acknowledgments}

This work was supported by Scientific Research Projects Coordination Unit of Bandırma Onyedi Eylül University, Project Number: BAP-19-1009-041.

\section{References}

Adams, W.M. (2003), "Nature and the colonial mind" in Decolonising nature: strategies for con-servation in a post-colonial Era W.M. Adams and M. Mulligan (eds.), p. 16-50, Earthscan, London.

Anderson, D.M., Salick, J., Moseley, R.K. and Xiaokun, O. (2005), "Conserving the sacred medicine mountains: a vegetation analysis of Tibetan sacred sites in Northwest Yunnan", Biodiversity. Conservation, no. 14, p. 3065-3091.

Arı, Y. (2004), "Environmental Impacts of Cılbak Rituals at Kazdağı National Park, Turkey", Proceedings of the Third Turkey-Romania Geographic Academic Seminar, p. 224-230, Inkılap Kitabevi, İstanbul.

Arı, Y. (2008), "Eko turizm mi ego turizm mi? Kazdağı (Balıkesir) Örneği", TUCAUM V. Ulusal Coğrafya Sempozyumu Bildiriler Kitabı, p. 421-428, Ankara. 
Arı, Y. and Köse, A. (2009), "Cultural diversity and nature: nature conservation at Kazdagi National Park, Turkey" in Cultural diversity, K., Donert, Y., Arı, M., Attard, M. O'Rilly and D., Schmeinc (eds.) Herodot Book, Series no. 9, p. 2530 .

Arı, Y. and Soykan, A. (2006a), "Kazdağı Milli Parkı'nda kültürel ekoloji ve doğa koruma", Türk Coğrafya Dergisi, no. 44, p. 11-32.

Arı, Y. and Soykan, A. (2006b), "Kazdağı Milli Parkı'nın yerel toplumlar üzerindeki ekonomik ve sosyal etkileri", Kazdağlar 2. Ulusal Sempozyumu Bildiriler Kitabı, p. 234-245, Çanakkale.

Avcı, D. (2017), "Mining conflicts and transformative politics: A comparison of Intag (Ecuador) and Mount Ida (Turkey) environmental struggles", Geoforum, no. 84 , p. 316-325.

Avc1, D., Adaman, F. and Özkaynak, B. (2010), "Valuation languages in environmental conflicts: How stakeholders oppose or support gold mining at Mount Ida, Turkey", Ecological Economics, vol. 70, no. 2, p. 228-238.

Berkes, F. (1999), Sacred ecology: traditional ecological knowledge and resource management, Taylor and Francis, Philadelphia and London.

Berkes, F. (2008), Sacred Ecology, Traditional Ecological Knowledge and Resource Management, Routledge, New York and London.

Berkes, F. (2012), Sacred Ecology ( $3^{\text {rd }}$ Edition), Routladge, New York.

Berkes, F. and Folke, C. (1998), "Linking social and ecological systems for resilience and sustainability", Beijer Discussion Paper Series, no. 52. Stockholm, Sweden.

Berkes, F. Colding, J. and Folke, C. (2000). "Rediscovery of traditional ecological knowledge as adaptive management", Ecological applications, vol. 10, no. 5, p. 1251-1262.

Bernbaum, E. (2012), "Sacred Mountains and Global Changes: Impacts and Responses" in Sacred Natural Sites, B., Verschuuren, J., McNeely, G., Oviedo and R. Wild, (eds.), p. 59-67, Routledge.

Bulut, I. (2011), "Anadolu'da inanışların ve geleneklerin doğa korunması açısından önemi üzerine örnekler", Atatürk Üniversitesi Edebiyat Fakültesi Sosyal Bilimler Dergisi, vol.11, no.46, p.119-134.

Campbell, M.O. (2005), "Sacred groves for forest conservation in Ghana's coastal savannas: assessing ecological and social dimensions", Singapore Journal of Tropical Geography, vol. 26, no. 2, p.151-169.

Çelik, S. Karabacak, E. and Uysal, I. (2008), "Plants have been collected from mythological Kazdağı (mt. Ida) National Park, West Turkey by Turkmens and their folk, cultural and social uses", European Journal of Scientific Research, vol. 4, p. 835-843.

Çetin, B. Șahin, K. and Coșkun, M. (2017), "Disiplinler arası yaklașımla bir kutsal mekânın olușumu, peyzajı ve fonksiyonel özellikleri: Pir Hatip ziyareti (Nusaybin)", Turkish Studies, vol. 12, no. 21, p. 179-206.

Colding, J. and Folke, C. (1997), "The relations among threatened species, their protection, and taboos", Conservation Ecology, 20 June 2020, shorturl.at/ckuST. 
Dereli, D. and Arı, Y. (2012), "Kazdağı Milli Parkı'nda Ziyaretçi Yönetimi", Kazdağları III. Ulusal Sempozyumu Bildirileri Kitabı, p. 179-186. Balıkesir.

Dudley, N., Higgins-Zogib, L. and Mansourian, S. (2009), "The links between protected areas, faiths, and sacred natural sites", Conservation Biology, vol. 23, no. 3, p. 568-577.

Dudley, N., Hockings, M. and Stolton, S. (2003), Protection assured: guaranteeing the effective management of the world's protected areas-a review of options. A background paper for the World Commission of Protected Areas, IUCN, Gland, Switzerland.

Dudley, N., Higgins-Zogib, L. and Mansourian, S. (eds.) (2005), Beyond Belief: Linking faiths and protected areas to support biodiversity conservation. A research report by WWF, Equilibrium and The Alliance of Religions and Conservation (ARC), World Wide Fund for Nature.

Duymaz, A. (2001), "Kazdağı ve Sarıkız efsaneleri üzerine bir değerlendirme", Balıkesir Üniversitesi. Sosyal Bilimler Enstitüsü Dergisi, vol. 4, no. 5, p. 88-102.

Duymaz, A. and Şahin, H.İ. (2008), "Kaz dağlarında dağ, ağaç ve ocak kültü", Bahkesir Üniversitesi Sosyal Bilimler Enstitüsü Dergisi, vol. 11, no.19, p. 116-126.

Frascaroli, F. (2013), "Catholicism and conservation: The potential of sacred natural sites for biodiversity management in Central Italy", Human Ecology, vol. 41. no. 4, p. 587-601.

Frascaroli, F., Bhagwat, S. and Diemer, M. (2014), "Healing animals, feeding souls: ethnobotanical values at sacred sites in Central Italy", Economic Botany, vol. 68 , no. 4 , p. $438-451$.

Harmon, D. (2007), "A Bridge over the Chasm: Finding ways to achieve integrated natural and cultural heritage conservation", International Journal of Heritage Studies, vol. 13, no. 4/5, p. 380-392.

Hurley, P.T. and Arı, Y. (2011), "Mining (dis) amenity: The political ecology of mining opposition in the Kaz (Ida) mountain region of western Turkey" Development and Change, vol. 42, no. 6, p. 1393-1415.

Hurley, P.T. and Arı, Y. (2018) "Saying "No" to (the) Oxygen Capital? Amenity migration, counter-territorialisation, and uneven rural landscape change in the Kaz Dağları (Ida Mountains) of western Turkey", Journal of Rural Studies, vol. 62, p. 195-208.

Jackson, W. and Ormsby, A. (2017), "Urban sacred natural sites-a call for research", Urban Ecosystems, vol. 20, no. 3, p. 675-681.

KDMP, (2020), Kazdă̆ National Park Official Web Site, 01 February 2020, http://kazdagi.tabiat.gov.tr/.

Köse, A. (1997), "Kaz Dağı'nda doğal çevre özelliklerine dayanan günübirlik rekreasyon alanlarına üç örnek: Ayazma, Pınarbașı ve Sütüven", Türk Coğrafya Dergisi, no.32, p. 237-262.

Lebbie, A.R. and Guries, R.P. (1995), "Ethnobotanical value and conservation of sacred groves of the Kpaa Mende in Sierra Leone", Economic Botany, vol. 49, no. 3, p. 297-308.

Maffi, L. (2012), "What is biocultural diversity" in Biocultural diversity conservation: a global sourcebook, L. Maffi and E. Woodley (eds), p.1-11, Routledge. 
Malhotra, K.C., Gokhale, Y., Chatterjee, S. and Srivastava, S. (2001), Cultural and ecological dimensions of sacred groves in India, Indian National Science Academy, New Delhi.

Mallarach, J.M. (2010), "Applicability of the IUCN-UNESCO Guidelines for protected area managers on sacred natural sites: first assessment", The Diversity of Sacred Lands" Europe: Proceedings of the Third Workshop of the Delos InitiativeInari/Aanaar, p. 260-270.

Mallarach, J.M. and Papayannis, T. (2007), "Protected areas and spirituality", Proceedings of the First Workshop of the Delos Initiative, IUCN, Gland.

Metcalfe, K., French-Constant, K. and Gordon, I. (2009), "Sacred sites as hotspots for biodiversity: The Three Sisters Cave complex in coastal Kenya", Oryx, vol. 44, no. 1, p.118-123.

Nasr, S.H. (1996), "Religion and the order of nature: the 1994 Cadbury lectures at the University of Birmingham", Quarterly Review of Biology, vol. 72, no. 4, p. 453.

Öner, N., Özden, S. and Birben, Ü. (2010), "Relationship between a natural monumental stand in Turkey and local beliefs", Journal of Environmental Biology, vol. 31, no. 1, p. 149-155.

Oviedo, G. Jeanrenaud, S. and Otegui, M. (2005), Protecting Sacred Natural Sites of Indigenous and Traditional Peoples: An IUCN Perspective, Gland, Switzerland, 20 June 2020, shorturl.at/fhFJL.

Özkan, O. and Uzun, A. (2019), "Spatial perceptions and thoughts of retirement migrants in the case of Kazdağı (Ida Mountain) National Park and its vicinity (Balıkesir-Turkey)", Turkish Journal of Geographical Sciences, vol. 17, no. 2, p. 237 259.

Posey, D. (ed.) (1999), Cultural and Spiritual Values of Biodiversity, A Comprehensive Contribution to the UNEP Global Biodiversity Assessment, Intermediate Technology Publications, London, 20 June 2020, shorturl.at/ijCKY.

Pretty, J., Adams, B., Berkes, F., de Athayde, S.F., Dudley, N., Hunn, E., Maffi, L., Milton, K., Rapport, D., Robbins, P., Sterling, E., Stolton, S., Tsing, A., Vintinnerk, E. and Pilgrim, S. (2009), "The intersections of biological diversity and cultural diversity: towards integration", Conservation and Society, vol. 7, no. 2, p. 100-112.

Pungetti, G., Oviedo, G. and Hooke, D. (eds.) (2012), Sacred Species and Sites: Advances in Biocultural Conservation, Cambridge University Press.

Rutte, C. (2011), "The sacred commons: conflicts and solutions of resource management in sacred natural sites", Biological Conservation, vol. 144, no. 10, p. 2387-2394.

Samakov, A. and Berkes, F. (2017), "Spiritual commons: sacred sites as core of community-conserved areas in Kyrgyzstan", International Journal of the Commons, vol. 11, no. 1, p. 422-444.

Satıl, F., Dirmenci, T. and Tümen, G. (2006), "Kazdağı Milli Parkının öncelikli koruma alanlarının sınıflandırılması ve önemli bitkileri", Kazdağları II. Ulusal Sempozyumu, p. 391-401. Çanakkale. 
Satıl, F., Tümen, G., Dirmenci, T., Arı Y., Çelik, A. and Malyer, H. (2006), "Kazdağı Milli Parkı ve Çevresinde (Balıkesir) Etnobotanik Envanter Çalıșması 2004-2006", Türkiye Bilimler Akademisi, Kültür Envanteri Dergisi, no. 5, p. 171-203.

Satıl, F. (2009), "Threatening factors on plant diversity of Kazdağ (Ida mountain) national park in Turkey and suggestions for conservation", Biotechnology $\mathcal{E}^{\circ}$ Biotechnological Equipment, vol. 23, no. 2, p. 208-221.

Schaaf, T. and Lee, C. (Eds.) (2006), Conserving Cultural and Biological Diversity: The Role of Sacred Natural Sites and Cultural Landscapes, UNESCO, Paris.

Shen, X., Lu, Z., Li, S. and Chen, N. (2012), "Tibetan sacred sites: understanding the traditional management system and its role in modern conservation", Ecology and Society, vol. 17, no. 2, p. 13.

South Marmara Development Agency (2020), Balıkesir Turizm Yatrrm Rehberi, 17 September 2020, shorturl.at/nwER5.

Stepp, J.R., Cervone, S., Castaneda, H., Lasseter, A., Stocks, G. and Gichon, Y. (2004), "Development of a GIS for Global Biocultural Diversity", Policy Matters, vol. 13, p. 267-270.

Tatar, B. (2017), "Kutsal mekan': Fenomenolojik bir analiz", Milel ve Nihal, vol. 14 , no. 2, p. 8-22.

Tengö, M. and von Heland, J. (2011), "Adaptive capacity of local indigenous institutions: the case of the taboo forests of southern Madagascar" in Adapting institutions. Governance, Complexity and Social-ecological Resilience, E. Boyd and C. Folke (eds.), Cambridge University Press, Cambridge.

Thorley, A. and Gunn, C.M. (2008), Sacred Sites: An Overview, The Gaia Foundation, Bath.

Turner, N.J., Ari, Y., Berkes, F., Davidson-Hunt, I., Ertug, Z.F. and Miller, A. (2009), "Cultural management of living trees: an international perspective", Journal of Ethnobiology, vol. 29, no. 2, p. 237-270.

UNDRIP (2007), Declaration on the rights of indigenous peoples, United Nations, General Assembly, 61 ${ }^{\text {st }}$ session, agenda item 68, Report of the Human Rights Council, UNESCO, Paris.

Uysal, I. (2010), "An overview of plant diversity of Kazdagi (Mt. Ida) Forest National Park, Turkey", Journal of Environmental Biology, vol. 31, no 1/2, p. 141147.

Uzun, A. and Özkan, O. (2019), "Emekli göçü literatürünün değerlendirilmesi", Eastern Geographical Review, vol. 24, no. 41, p. 141-152.

Uzun, A. and Yıldız, B. (2020), "Cultural geography of sacred places: The case study of Nazımiye District (Tunceli)", International Journal of Geography and Geography Education (IGGE), no. 41, p. 129-140.

Verschuuren, B., Mallarach, J.M. and Oviedo, G. (2007). Sacred Sites and Protected Areas. IUCN Categories of Protected Areas Summit, Almeria, Spain. Gland, Switzerland: IUCN, 164-169.

Verschuuren, B., Wild, R., McNeely, J.A. and Oviedo, G. (eds.) (2010), Sacred Natural Sites: Conserving Nature and Culture, Earthscan, London. 
Verschuuren, B., McNeely, J., Oviedo, G. and Wild, R. (2012), "Introduction: Sacred Natural Sites the Foundations of Conservation", Sacred Natural Sites, p. 27-40, Routledge.

Wild, R. and McLeod, C. (2008), Sacred Natural Sites. Guidelines for Protected Area Managers, IUCN, Gland, Switzerland.

Yürüdür, E. and Toksoy, M. (2017), "Halk kültürü ve doğa koruma: Tokat örneği", Gaziosmanpașa Üniversitesi Sosyal Bilimler Araștırmalarn Dergisi, vol. 12, no. 2, p. 161-176. 